\title{
PENGGUNAAN ANTIKEJANG PADA CEDERA KEPALA: TINJAUAN SISTEMATIS
}

\author{
Safa Nabila Zafira, Diva Aulya Kemuning, Nur Izzatush Sholihah, Muhammad \\ Nooradi Praramdana \\ Program Studi Pendidikan Dokter, Fakultas Kedokteran, Universitas Mataram, \\ Email: safanabila5@gmail.com, divaaulyakemuning@gmail.com, \\ nurizzatush@gmail.com, Nooradiaksel8@gmail.com
}

\begin{abstract}
Abstrak
Cedera kepala dapat terjadi karena adanya benturan kepala secara langsung dan cedera akibat kerusakan jaringan otak seperti hipotensi, hipoksia, asidosis dan edema. Terjadinya cedera kepala akan memicu proses inflamasi yang dapat mencetuskan terjadinya kejang pasca cedera. Tujuan studi ini untuk mengetahui peran anti kejang pada kejadian kejang pasca trauma. Metode yang digunakan dalam penulisan ini adalah tinjauan sistematis yang relevan dari berbagai referensi dan terfokus pada penggunaan analgetik sebagai tatalaksana kejang akibat cedera otak. Pencarian literatur menggunakan PubMed dan didapatkan 7 literatur yang memenuhi kriteria. Terdiri dari 1 studi RCT dan 6 studi observasional. Pemberian terapi profilaksis pada kejadian cedera kepala efektif untuk mencegah terjadinya kejang pasca trauma. Penggunaan anti kejang dapat diberikan pada pasien cedera kepala traumatis sedang maupun berat dan dapat diberikan kurang dari 12 jam setelah cedera untuk mencegah kejang. Terapi profilaksis hanya disarankan digunakan selama 7 hari setelah cedera kepala. Anti kejang yang sering digunakan sebagai agen profilaksis yaitu fenitoin dan levetiracetam. Adapun lacosamide direkomendasikan untuk pengguna dengan status epileptikus refrakter. Levetiracetam memiliki efek samping yang lebih sedikit daripada fenitoin dan lacosamide sehingga penggunaan obat ini lebih dianjurkan untuk digunakan. Pemberian anti kejang pada kasus kejang pasca traumatic brain injury (TBI) atau post traumatic seizure (PTS) digunakan sebagai usaha profilaksis kejang dengan rekomendasi pemakaian kurang dari delapan hari karena OAE terbukti memiliki beberapa efek samping setelah penggunaannya termasuk dapat meningkatkan angka mortilitas. Terkhusus pada pemberian fenitoin dan lacosamide diperlukan adanya pemantauan saat penggunaannya.
\end{abstract}

Kata Kunci: Fenitoin; Levetiracetam; Cedera Otak; Epilepsi Pasca Trauma

\section{Abstract}

Brain injury can occur due to direct head impact and injury due to brain tissue damage such as hypotension, hypoxia, acidosis and edema. Brain injury will trigger an inflammatory process that can lead to post-trauma seizures. The use of anti-epileptic drugs is intended as a seizure prophylaxis so that it can reduce the incidence of seizures in the early phase of injury. Quantify the effectivity of anti

\footnotetext{
Copyright holder: Safa Nabila Zafira, Diva Aulya Kemuning, Nur Izzatush Sholihah, Muhammad Nooradi Praramdana (2022)

DOI $\quad: 10.54543 /$ fusion.v2i1.138

Published by : Rifa Institute
} 
Safa Nabila Zafira, Diva Aulya Kemuning, Nur Izzatush Sholihah, Muhammad Nooradi Praramdana

seizure usage on post traumatic seizure accident. The method used in this paper is a relevant systematic review from various references and focuses on the use of analgesics for the management of seizures due to brain injury. The literature search used PubMed and found 7 literature that met the criteria. Consists of 1 RCT study and 6 observational studies. Prophylactic therapy in the incidence of head injury is effective in preventing PTS. The use of anti seizure can be given to patients with moderate or severe TBI and can be given less than 12 hours after injury to prevent seizures. Prophylactic therapy is only recommended for 7 days after head injury. Anti seizure drug which is often used as a prophylactic agent are phenytoin and levetiracetam. Lacosamide is recommended for users with refractory status epilepticus. Levetiracetam has fewer side effects than phenytoin and lacosamide, so the use of this drug is preferable to use. Using Anti seizure in cases of post-traumatic brain injury (TBI) or post traumatic seizure (PTS) is behoof as a seizure prophylactic attempt by using recommendation less than eight days because OAE has been shown several side effects, include increasing mortality. Especially for using phenytoin and lacosamide, it is necessary to monitor.

Keywords: Phenytoin; Levetiracetam; Post Traumatic Seizure; Brain Injury; Post Traumatic Epilepsy

Diterima: 20-12-2021Ｄirevisi: 06-01-2022Ｄiterbitkan: 20-01-2022

\section{Pendahuluan}

Menurut Brain Injury Association of America, cedera kepala didapat merupakan suatu kejadian cedera yang didapat dan yang tidak diturunkan, tidak bersifat bawaan, degeneratif, atau disebabkan oleh trauma saat lahir. Cedera kepala ini dapat memengaruhi kemampuan fungsional sel saraf di otak. $C D C$ mendefinisikan cedera kepala traumatis sebagai gangguan pada fungsi normal otak yang dapat disebabkan oleh adanya benturan, pukulan, atau sentakan pada kepala, atau cedera kepala tembus. Cedera kepala traumatis sedang hingga berat merupakan salah satu penyebab kematian dan kecacatan pada anak-anak dan dewasa (Shaikh and Waseem, 2021).

Pasien dengan cedera kepala berat memiliki tingkat risiko terjadi kejang pasca trauma sebesar 12\%. Post traumatic seizures terjadi pada $19,4 \%$ populasi di dunia (Valeria et al,2021). Saat ini insiden kematian akibat brain injury di Asia Tenggara sebesar $1,5 \%$ dari populasi pertahun sementara di Eropa memiliki angka yang lebih kecil yaitu 1,2\% per populasi per tahun. Cedera kepala traumatis ini dapat mencetuskan beberapa gejala yang timbul sebagai akibat dari cedera yang dialami salah satunya yakni kejang/post traumatic seizure. Kejang pasca trauma diklasifikasikan atas kejang dini dan kejang lambat. Kejang yang terjadi dalam waktu 7 hari setelah trauma disebut kejang onset dini, sedangkan kejang onset lambat merupakan kejang yang terjadi $>7$ hari setelah terjadi trauma. Sedangkan kejang berulang yang terjadi 7 hari pasca trauma disebut epilepsi pasca trauma atau post-traumatic epilepsy (PTE) (Carney et al., 2017). 
Penyakit ini dialami oleh sebagian besar pasien TBI laki-laki dibanding perempuan dengan perbandingan 3,5:1 (Valeria et al ,2021). Berdasarkan waktunya, pasien yang mengalami post traumatic seizure dengan TBI yang terjadi pada kejang awal ( $<7$ hari) sebanyak 4-25\%, kejang lambat ( $>7$ hari) $9-42 \%$, dan kejang segera $(<24$ jam) 1-4\% (Chris Nickson, 2020). Penggunaan obat anti kejang pada kasus TBI dan sebagai profilaksis PTS disarankan digunakan selama 7 hari pasca TBI (Torbic et al., 2013). Profilaksis kejang merupakan pemberian antikonvulsan kepada pasien yang mengalami cedera kepala untuk mengantisipasi atau mencegah terjadinya kejang (Carney et al., 2017).

Beberapa neurologis menyarankan untuk pemberian obat antiepilepsi (OAE) pada kasus dengan risiko tinggi seperti trauma kepala derajat berat dan digunakan selama 7 hari pasca trauma (Khan et al., 2016). Fenitoin merupakan salah satu obat anti kejang yang sering digunakan. Penggunaan fenitoin juga memiliki beberapa efek samping serta interaksi obat yang cukup merugikan. sehingga dibutuhkan penemuan anti kejang baru sebagai lini pertama profilaksis kejang terutama kejang onset dini pasca trauma. Berkaitan dengan hal ini, studi mengenai levetiracetam saat ini juga cukup meningkat.

\section{Metode Penelitian}

Pencarian literatur dilakukan dengan menggunakan database PubMed. Pencarian literatur yang relevan dengan topik ini dilakukan dengan menggunakan kata kunci phenytoin, levetiracetam, post traumatic seizure, brain injury, antiepileptic drugs, post traumatic epilepsy. Kriteria inklusi yang digunakan antara lain literatur dipublikasi dalam rentang tahun 2011-2021, literatur ditulis dalam bahasa Inggris, literatur menggunakan studi intervensi, studi observasi, randomized controlled trials (RCT), studi menggunakan anti kejang atau antiepilepsi sebagai manajemen pada kasus cedera otak pada pasien dewasa. Alur hasil pencarian literatur disajikan pada Gambar 1.

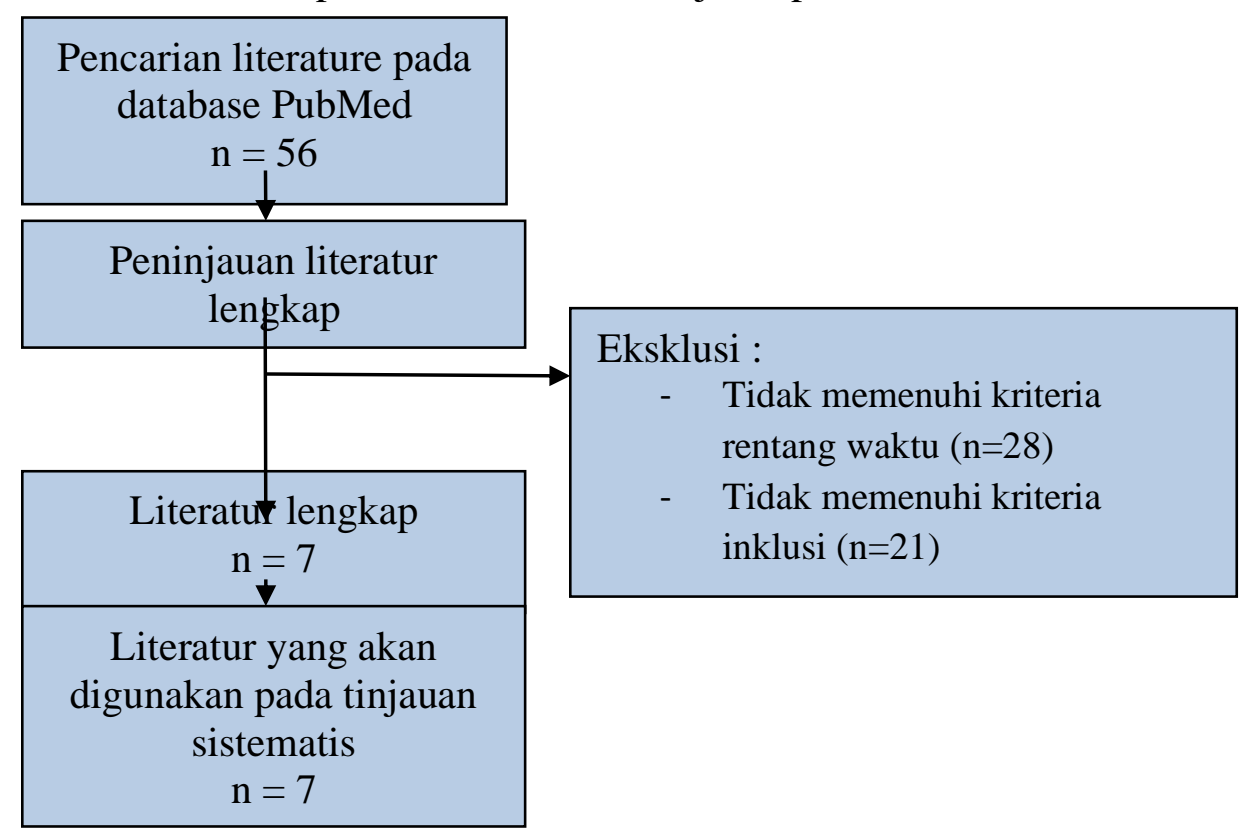


Safa Nabila Zafira, Diva Aulya Kemuning, Nur Izzatush Sholihah, Muhammad Nooradi Praramdana

Gambar 1. Alur pencarian literatur

\section{Hasil dan Pembahasan}

Berdasarkan hasil pencarian didapatkan 7 literatur yang memenuhi kriteria inklusi dan relevan untuk digunakan. Ringkasan hasil pencarian literature disajikan pada Tabel 1 . 


\begin{tabular}{|c|c|c|c|c|}
\hline $\begin{array}{l}\text { Penulis } \\
\text { (Tahun) }\end{array}$ & $\begin{array}{c}\text { Desain } \\
\text { penelitia } \\
\mathbf{n}\end{array}$ & Populasi sampel & Perlakuan & Hasil \\
\hline
\end{tabular}




\begin{tabular}{|c|c|c|c|c|}
\hline & & & $\begin{array}{l}\text { dengan loading dose } 20 \mathrm{mg} / \mathrm{Kg} \\
\text { secara intravena selama } 1 \text { jam } \\
\text { dan diikuti dosis pemeliharaan } \\
10-20 \mathrm{mg} / \mathrm{Kg} / \mathrm{hari} \text { dibagi atas } \\
\text { dua dosis. Kedua kelompok di } \\
\text { observasi hingga hari ketuju } \\
\text { pasca trauma untuk menilai } \\
\text { efikasi pemberian obat terhadap } \\
\text { kejang pasca trauma onset dini }\end{array}$ & \\
\hline $\begin{array}{l}\text { Javed, dkk } \\
(2016)\end{array}$ & $\begin{array}{l}\text { Retrospec } \\
\text { tive } \\
\text { cohort }\end{array}$ & $\begin{array}{l}\text { Jumlah pasien sebanyak } 100 \text { pasien } \\
\text { dengan } 50 \text { pasien tiap kelompoknya. } \\
\text { Studi dilakukan di Rumah Sakit } \\
\text { Universitas Aga Khan di Karachi } \\
\text { dengan rentang waktu } 1 \text { Juli } 2010 \\
\text { hingga } 31 \text { Maret } 2011 .\end{array}$ & $\begin{array}{l}\text { Pasien dikategorikan atas } 2 \\
\text { kelompok. Pasien pada } \\
\text { kelompok } 1 \text { merupakan pasien } \\
\text { yang awalnya diberikan fenitoin } \\
\text { kemudian diganti dengan } \\
\text { pemberian levetiracetam secara } \\
\text { enteral pada hari ketiga pasca } \\
\text { trauma kepala dengan dosis } 35 \\
\text { mg/Kg per dosis dengan } 3 \text { kali } \\
\text { pemberian. Kemudian pasien } \\
\text { pada kelompok } 2 \text { merupakan } \\
\text { kelompok pasien yang diberikan } \\
\text { fenitoin saja. }\end{array}$ & $\begin{array}{l}\text { Tidak didapatkan perbedaan yang } \\
\text { signifikan antara pemberian } \\
\text { levetiracetam setelah pemberian awal } \\
\text { fenitoin dengan yang hanya diberikan } \\
\text { fenitoin saja. Didapatkan resiko relatif } \\
\text { kejang onset dini pasca trauma yang } \\
\text { sebanding diantara kedua kelompok. }\end{array}$ \\
\hline $\begin{array}{l}\text { Candy, } \\
\text { dkk. }\end{array}$ & $\begin{array}{l}\text { Retrospec } \\
\text { tive case- }\end{array}$ & $\begin{array}{l}\text { Pasien cedera kepala di Flinders } \\
\text { Medical Center dari mei 2013- juni }\end{array}$ & $\begin{array}{l}\text { Seluruh pasien di seleksi dengan } \\
\text { kriteria inklusi dan ekslusi }\end{array}$ & $\begin{array}{l}610 \text { pasien mengalami trauma otak } \\
\text { ringan, sedang atau berat. Sebanyak } 16 \%\end{array}$ \\
\hline
\end{tabular}




\begin{tabular}{|c|c|c|c|c|}
\hline (2019) & note & 2017 & $\begin{array}{l}\text { sehingga tersisa } 610 \text { pasien. } \\
\text { Kemudian pasien dibagi } \\
\text { berdasarkan klasifikasi tingkat } \\
\text { cedera dan dibagi berdasarkan } \\
\text { pemberian OAE profilaksis }\end{array}$ & $\begin{array}{l}\text { pasien diberi resep OAE profilaksis dan } \\
90 \% \text { diberikan Levetiracetam. } \\
\text { Levetiracetam merupakan obat yang } \\
\text { paling sering diresepkan. Pasien yang } \\
\text { diresepkan OAE dan mengalami PTS } \\
\text { onset dini sebanyak 2,9\%. Pasien yang } \\
\text { tidak diberi resep OAE dan mengalami } \\
\text { PTS yaitu 3,5\% (OR 0.83 CI 0.24-2.85 p } \\
=1 \text { ). Pada studi ini pemberian profilaksis } \\
\text { pada TBI berat tidak memberi manfaat } \\
\text { secara signifikan terhadap munculnya } \\
\text { PTS dini }\end{array}$ \\
\hline $\begin{array}{l}\text { Gul,. Dkk. } \\
\text { (2019) }\end{array}$ & $\begin{array}{l}\text { Cross- } \\
\text { sectional }\end{array}$ & $\begin{array}{l}\text { Semua pasien dengan cedera kepala } \\
\text { sedang hingga cedera kepala berat di } \\
\text { departemen Bedah Saraf Ayub Medical } \\
\text { College dari April hingga oktober } \\
\text { 2015. Usia nya dalam rentang 5-50 } \\
\text { tahun }\end{array}$ & $\begin{array}{l}\text { Pasien yang mengalami cedera } \\
\text { yang datang dalam waktu } 48 \\
\text { jam. Kemudian dibagi menjadi } 2 \\
\text { kelompok yaitu yang mengalami } \\
\text { cedera <12 jam dan }>12 \text { jam. } \\
\text { Kemudian setiap kelompok } \\
\text { diberi fenitoin saat pertama } \\
\text { masuk dengan dosis awal } 20 \\
\text { mg/kg secara i.v selama } 60 \text { menit } \\
\text { kemudian diberi dosis } \\
\text { pemeliharaan } 50 \text { mg/kg/hari } \\
\text { dalam } 2 \text { dosis terbagi. Pasien } \\
\text { diamati selama } 7 \text { hari pasca }\end{array}$ & $\begin{array}{l}\text { Sebanyak } 16 \% \text { pasien mengalami kejang } \\
\text { pasca trauma dini dan sisanya } 84 \% \text { bebas } \\
\text { kejang setelah diberi fenitoin. } \\
\text { Perbedaannya signifikan secara statistik } \\
\text { (nilai-p .018). Frekuensi kejang pasca } \\
\text { trauma dini didapatkan hasil yang tinggi } \\
\text { pada pasien cedera kepala sedang sampai } \\
\text { berat }\end{array}$ \\
\hline
\end{tabular}




\begin{tabular}{|c|c|c|c|c|}
\hline & & & $\begin{array}{l}\text { trauma untuk menilai adanya } \\
\text { kejang }\end{array}$ & \\
\hline $\begin{array}{l}\text { Kwon, } \\
\text { dkk. } \\
\text { (2019) }\end{array}$ & $\begin{array}{l}\text { Studi } \\
\text { kohort } \\
\text { retrospekt } \\
\text { if }\end{array}$ & $\begin{array}{l}\text { Seluruh pasien yang dirawat dari } \\
\text { Agustus } 2012 \text { hingga September } 2016 \\
\text { dengan monoterapilacosamide atau } \\
\text { fenitoin sebagai profilaksis kejang } \\
\text { pasca TBI yang diidentifikasi } \\
\text { menggunakan pencatatan trauma } \\
\text { institusi dan rekam medis elektronik. }\end{array}$ & $\begin{array}{l}\text { Pasien yang dilibatkan adalah } \\
\text { pasien yang datang dalam waktu } \\
24 \text { jam setelah cedera, memiliki } \\
\text { inisiasi profilaksis kejang dalam } \\
24 \text { jam setelah ditangani, berusia } \\
\geq 18 \text { tahun, dan memiliki hasil } \\
\text { CT scan yang menunjukkan } \\
\text { adanya perdarahan subarachnoid, } \\
\text { perdarahan subdural, perdarahan } \\
\text { epidural, perdarahan } \\
\text { intraparenkim, atau perdarahan } \\
\text { intraventrikular maupun memar } \\
\text { kortikal.. Adapun dosis } \\
\text { profilaksis yang diberikan untuk } \\
\text { lacosamide adalah } 50 \text { mg dua } \\
\text { kali sehari (jika skor total GCS } \\
\text { pasien 13-15) atau } 200 \text { mg } \\
\text { sekali, diikuti dengan pemberian } \\
100 \text { mg lacosamide dua kali } \\
\text { sehari (jika skor total GCS } \leq 12 \\
\text { atau memiliki lesi struktural } \\
\text { berat). Dosis fenitoin adalah } 15- \\
20 \text { mg/kgdiikuti } 300-400 \text { mg }\end{array}$ & $\begin{array}{l}\text { Tidak ditemukan adanya } \\
\text { perbedaaninsiden PTS pasca TBI antara } \\
\text { pasien yang diberikan lacosamide atau } \\
\text { fenitoin.Diketahui } \\
\text { lacosamidememilikiefek samping yang } \\
\text { lebih bisa ditoleransi dibandingkan } \\
\text { fenitoin yang dikaitkan dengan adanya } \\
\text { Advers Drug Events (ADE) akibat } \\
\text { penghentian obat pada fenitoin memiliki } \\
\text { kadar yang lebih tinggi secara signifikan. }\end{array}$ \\
\hline
\end{tabular}


setiap hari. Durasi pemakaian

profilaksis adalah 7 hari.

\begin{tabular}{|c|c|c|c|c|}
\hline $\begin{array}{l}\text { Harris, } \\
\text { dkk. } \\
(2020)\end{array}$ & $\begin{array}{l}\text { Studi } \\
\text { observasi } \\
\text { onal } \\
\text { retrospekt } \\
\text { if }\end{array}$ & $\begin{array}{l}\text { Seluruh pasien yang dirawat di Major } \\
\text { Trauma Unit, London pasca TBI } \\
\text { dengan monoterapi levetiracetam atau } \\
\text { fenitoin sebagai profilaksis kejang dini } \\
\text { antara Oktober } 2013 \text { dan Juni } 2018 \text {. }\end{array}$ & $\begin{array}{l}\text { Pasien dikategorikan } \\
\text { berdasarkan skor total Glasgow } \\
\text { Coma Scale (GCS) yakni } \\
\text { minimal } 14 \text { atau lebih, dan lama } \\
\text { tinggal pada unit trauma kurang } \\
\text { dari } 3 \text { minggu. Setiap pasien } \\
\text { dinilai oleh tim trauma therapy, } \\
\text { pasien dengan 'pusing' akan } \\
\text { menjalani pengukuran tekanan } \\
\text { darah dan melakukan } \\
\text { elektrokardiogram untuk } \\
\text { menyingkirkan penyebab } \\
\text { kardiovaskular, dan pemeriksaan } \\
\text { elektrolit serum serta tes fungsi } \\
\text { hati termasuk amonia untuk } \\
\text { menyingkirkan ensefalopati. } \\
\text { Apabila terdapat kecurigaan } \\
\text { klinis, pasien akan mendapatkan } \\
\text { transthoracic echocardiogram } \\
\text { untuk menyelidiki penyebab } \\
\text { terkait jantung. Selanjutnya, } \\
\text { pasien ditinjau oleh konsultan } \\
\text { ahli saraf untuk dinilai terkait }\end{array}$ & $\begin{array}{l}\text { Levetiracetam, digunakan untuk } \\
\text { profilaksis kejang dini pasca TBI, yang } \\
\text { berkaitan dengan lama rawat inap lebih } \\
\text { pendek disertai pusing yang lebih ringan, } \\
\text { dibandingkan fenitoin. Diketahui pula } \\
\text { bahwa pusing maupun gejala penyakit } \\
\text { lainnya dapat menjadi salah satu faktor } \\
\text { yang berkontribusi pada proses } \\
\text { pemulihan pasien pasca TBI. }\end{array}$ \\
\hline
\end{tabular}


ataksia, okulomotor, gaya berjalan, dan disfungsi vestibular yang merupakan beberapa karakteristik dari pusing (misalnya, suspected cerebellar versus vestibular dysfunction danAnti-epileptic drug (AED)related versus benign paroxysmal positional vertigo following trauma). Analisis dilakukan untuk mengidentifikasi tren pola resep obat anti-epilepsi dan membandingkan lama tinggal di rumah sakit dari semua pasien yang diobati dengan levetiracetam dan fenitoin. 
Penggunaan Antikejang Pada Cedera Kepala: Tinjauan Sistematis

\section{Karakteristik Partisipan}

Berdasarkan studi yang dilakukan oleh Caballero dkk (Caballero et al., 2013) dari 402 pasien terdapat 90 pasien yang memenuhi kriteria inklusi. Dari 90 pasien terdapat 18 pasien menerima levetiracetam dan 72 pasien menerima fenitoin. Median usia pada kelompok levetiracetam lebih tinggi dibandingkan dengan kelompok fenitoin (57 dengan 45 tahun; $\mathrm{p}=0,01)$. Penyebab umum trauma pada pasien terdiri atas kecelakaan kendaraan (41\%) dan jatuh (31\%). Untuk jenis trauma seringnya cedera kepala tumpul $(95,5 \%)$ dibandingkan dengan cedera kepala penetrasi $(4,4 \%)$. Fraktur kepala terdapat pada $12 \%$ pasien, kehilangan kesadaran terjadi pada 54\% pasien, dan kejang dalam 24 jam pasca trauma terdapat pada 5,5\% pasien. Berdasarkan GCS sebanyak 63,3\% pasien menderita cedera kepala berat dengan lokasi umum cedera pada daerah lobus frontal $(53,3 \%)$ dan tipe cedera yang umum yakni subdural hematoma $(55,6 \%)$. Prevalensi cedera pada lobus temporal lebih rendah pada kelompok levetiracetam (22\%) dibandingkan pada kelompok fenitoin $(61 \%)(\mathrm{p}=0,01)$ (Caballero et al., 2013).

Studi yang dilakukan oleh Khan dkk. (Khan, et al., 2016) terdiri dari 154 pasien yaitu 115 pasien $(74,7 \%)$ adalah laki-laki dan 29 pasien $(25,3 \%)$ adalah perempuan. Kisaran usia antara 7-48 tahun dengan rata-rata 24,15 \pm 9,56 tahun. Pada studi ini didapatkan 82 pasien $(53,2 \%)$ mengalami cedera kepala akibat jatuh, 64 pasien $(41,6 \%)$ mengalami kecelakaan lalu lintas dan 8 pasien $(5,2 \%)$ mengalami penyerangan sebagai penyebab cedera kepala. 91 pasien $(59,1 \%)$ mengalami cedera kepala sedang (GCS 813) sementara sisanya dari 63 pasien $(40,9 \%)$ mengalami cedera kepala parah (GCS dari 3-7). Untuk kriteria ekslusi pada penelitian ini yaitu pasien yang datang setelah 12 jam mengalami cedera otak traumatis, mengalami epilepsy berdasarkan catatan medis, pasien dengan elektrolit yang rusak $(\mathrm{Na}+>145 \mathrm{mEq} / \mathrm{L}, \mathrm{K}+>5.0 \mathrm{mEq} / \mathrm{L})$ dan gangguan fungsi ginjal (Kreatinin> $1.4 \mathrm{mg} / \mathrm{dl}$, Urea> $50 \mathrm{mg} / \mathrm{dl}$ ), dan pasien dengan riwayat kejang sebelum datang ke rumah sakit, pasien yang menjalani operasi dan pasien yang meninggal selama minggu pertama masuk juga dikeluarkan dari penelitian.

Studi yang dilakukan oleh Javed dkk (Javed et al., 2016) terdiri atas 100 pasien dengan 50 pasien di tiap kelompoknya. Pada kelompok 1 mean usia pasien 31,16 +/17,39 tahun sedangkan pada kelompok $234,96+/-18,26$ tahun $(\mathrm{p}=1,06) .5$ pasien pada kelompok 1 memiliki kejang pasca trauma sebelum dibawa ke ruang emergensi dibandingkan dengan kelompok 2 ( $\mathrm{p}=0,24)$ (Javed et al., 2016).

Penelitian yang dilakukan oleh Gul dkk (Gul, et al., 2019) terdiri dari 163 pasien yaitu 122 pasien $(74,8 \%)$ adalah laki-laki dan 41 pasien $(25,2 \%)$ adalah perempuan. Kisaran usia pada penelitian ini antara 6 hingga 48 tahun dengan rata-rata usia $24.69 \pm$ 10.186 tahun. Dari total 163 Sebanyak 13 pasien (8\%) berada dalam kelompok usia 510 tahun, 54 pasien $(33,1 \%)$ berada pada kelompok umur 11-20 tahun, 52 pasien $(31,9 \%)$ pada kelompok umur 21-30 tahun, 22 pasien (13,5\%) pada kelompok umur 3140 tahun dan 41-50 tahun. Sebanyak 90 pasien (55,2\%) datang karena riwayat jatuh, 57 pasien $(35 \%)$ memiliki riwayat kecelakaan lalu lintas dan 16 pasien $(9,8 \%)$ memiliki 
Safa Nabila Zafira, Diva Aulya Kemuning, Nur Izzatush Sholihah, Muhammad Nooradi Praramdana

riwayat serangan. Untuk tingkat keparahan cedera kepala, sebanyak 80 pasien $(49,1 \%)$ mengalami cedera kepala sedang, sebanyak 83 pasien $(50,9 \%)$ mengalami cedera kepala berat. CT-scan pasien mengungkapkan bahwa 43 (26,4\%) memiliki hematoma ekstradural, 34 (20,9\%) masing-masing memiliki hematoma subdural akut dan patah tulang tengkorak depresi, 23 pasien $(14,1 \%)$ memiliki perdarahan sub-arachnoid, 20 $(12,3 \%)$ pasien mengalami cedera aksonal difus dan hanya $9(5,5 \%)$ pasien mengalami perdarahan intraserebral. Pasien dengan cedera kepala yang parah, diketahui mengalami epilepsi sebelumnya, mengalami kejang setelah cedera dan pasien dengan elektrolit yang rusak, fungsi hati dan fungsi ginjal termasuk dalam eksklusi. Pada studi Retrospective case-note yang dilakukan Candy dkk. (Candy, et al.,2019) didapatkan sebanyak 2124 pasien dipulangkan dari pusat studi dengan hematoma intrakranial selama masa studi Mei 2013 hingga Juni 2017. 1496 pasien dikeluarkan karena etiologi hematoma non-trauma, dan 18 pasien dikeluarkan karena memiliki PTS sebelumnya. Tersisa 610 pasien, dengan 495 TBI ringan, 49 TBI sedang, dan 66 TBI berat. Usia ratarata adalah 71 tahun, dan sekitar 58\% adalah laki-laki.

Mekanisme cedera yang paling umum ditemukan adalah jatuh dari ketinggian terjadi pada 448 pasien (73\%). kecelakaan kendaraan bermotor 41 pasien (7\%), jatuh dari ketinggian > $3 \mathrm{~m}$ di 30 pasien (5\%) dan kecelakaan sepeda motor sebanyak 25 pasien (4\%). Studi yang dilakukan oleh Kwon, dkk. (2019) terdiri atas 481 pasien, 116 pasien menerima fenitoin dan 365 pasien menerima lacosamide. Demografi pada kedua kelompok tidak memiliki perbedaan, kecuali pada usia (50 \pm 21 dengan $58 \pm 22$ tahun) dan skor total GCS masuk (11,3 $\pm 4,3$ vs $12,5 \pm 3,8)$ yang lebih rendah pada kelompok fenitoin dengan ventilasi mekanis yang lebih tinggi dibandingkan lacosamide $(53 \%$ : 38\%) (Kwon et al., 2019).

Studi yang dilakukan oleh Harris, dkk (2020) terdiri atas 278 pasien yang dirawat dengan monoterapi fenitoin atau levetiracetam. Terdapat 100 pasien yang memenuhi kriteria inklusi tambahan berdasarkan skor total GCS 14 atau lebih dan lama rawat inap kurang dari 3 minggu sehingga diperlukn perubahan pengobatan dari fenitoin menjadi levetiracetam.100 pasien yang memenuhi kriteria tersebut mendapati operasi kecil, rawat inap di ITU, memiliki infeksidan komplikasi di rumah sakit. Selanjutnya kelompok tersebut dibandingkan dengan 178 pasien yang tidak memenuhi kriteria. Seluruh pasien mendapatkan AED berdasarkan kecurigaan klinis berupa kejang maupun memiliki lokasi patologi intrakranial pada CT scan. Adapun dosis rutin yang diberikan adalah fenitoin $300 \mathrm{mg}$ sekali sehari dan levetiracetam $500 \mathrm{mg}$ dua kali sehari kecuali terdapat perbedaan berat badan maupun usia (Harris et al., 2020).

Hasil dari literatur yang digunakan

Pada studi yang dilakukan oleh Caballero dkk (Caballero et al., 2013) tidak didapatkan perbedaan aktivitas kejang pada monitoring EEG yang signifikan pada kelompok levetiracetam (28\%) dengan kelompok fenitoin $(29 \%)(\mathrm{p}=0,99)$. Riwayat masuk ICU dan lama tinggal di rumah sakit juga tidak menunjukkan perbedaan yang 
signifikan antara kelompok levetiracetam (13 hari) dan fenitoin (18 hari) ( $\mathrm{p}=0,11)$. Mengenai pemberian OAE tambahan juga tidak didapatkan perbedaan yang signifikan antar kedua kelompok ( $22 \%$ vs $49 \%$; $\mathrm{p}=0,062$ ). Terkait biaya yang digunakan pada kelompok levetiracetam didapatkan total biaya yang lebih rendah (45 \$/hari) dibandingkan pada kelompok fenitoin (83 \$/hari) $(\mathrm{p}=0,19)$. Hal ini berkaitan dengan kecendrungan therapeutic drug monitoring (TDM) fenitoin pada institusi ini dibandingkan pada levetiracetam sehingga membutuhkan biaya yang lebih besar (Caballero et al., 2013).

Berdasarkan studi yang dilakukan Khan dkk didapatkan sebanyak 73 pasien $(94,8 \%)$ dari grup A tetap dalam keadaan bugar selama tujuh hari pertama setelah cedera kepala dan 4 pasien $(5,19 \%)$ mengalami kejang pasca-trauma dini. Dalam kelompok B $70(90,95 \%)$ pasien bebas dari kejang dan 7 pasien $(9,1 \%)$ mengalami kejang selama tujuh hari pertama setelah cedera kepala. Dapat disimpulkan bahwa fenitoin efektif dalam mencegah kejang pasca trauma dini pada $73(94,8 \%)$ pasien sedangkan pada $4(5,19 \%)$ pasien gagal mencegah kejang. Sedangkan levetiracetam efektif mengendalikan kejang pada $70(90,95 \%)$ kasus dan sisanya $7(9,1 \%)$ kasus tidak efektif (Khan, et al., 2016). Pada studi yang dilakukan Javed dkk kedua kelompok pasien akan dilakukan pengawasan EEG pasien kemudian dibandingkan. Dilakukan pemeriksaan EEG pada 7 pasien pada kelompok 1 dan pada kelompok 2, 5 orang pasien dilakukan pemeriksaan EEG ( $\mathrm{p}=0,76$ ). 2 pasien pada setiap kelompok memiliki hasil EEG yang positif untuk aktivitas kejang $(\mathrm{p}=1,00)$. Derajat trauma kepala berdasarkan klasifikasi Marshall pada pasien yang menjalani EEG ini sebanding $(p=0,29)$. Jumlah pasien dengan EEG yang abnormal lebih tinggi pada kelompok levetiracetam, walaupun pada kelompok levetiracetam memiliki jumlah pasien dengan trauma berat lebih tinggi tetapi memiliki perbedaan yang kurang signifikan dengan kelompok fenitoin sehingga disimpulkan pada studi ini tidak didapatkan perbedaan yang signifikan secara statistic insiden kejang pasca trauma yang menerima levetiracetam oral serta yang menerima fenitoin (Javed et al., 2016).

Pada studi yang dilakukan Candy dkk. (Candy, et al., 2019) sebanyak 102 pasien diresepkan profilaksis AED, sementara 508 pasien tidak diresepkan profilaksis apa pun. Pada 508 pasien yang tidak diresepkan profilaksis, total 18 pasien $(3,5 \%)$ memiliki PTS dini. Sedangkan dari 102 pasien yang diresepkan profilaksis AED, sebanyak 3 pasien (2,9\%) mengalami PTS dini. Obat levetiracetam merupakan AED yang paling umum diresepkan yaitu $93(91 \%)$ pasien. Fenitoin diresepkan pada 4 (4\%) pasien, valproate pada $2(2 \%)$ pasien, dan loading fenitoin yang diikuti oleh levetiracetam reguler diberikan pada $3(3 \%)$ pasien. Pada studi cross-sectional yang dilakukan Gul et al Sebanyak $91(55,8 \%)$ pasien mulai menggunakan fenitoin IV dalam 12 jam setelah cedera kepala dan sisanya $72(44,2 \%)$ dimulai setelah 12 jam cedera kepala. Sebanyak $26(16 \%)$ pasien diamati mengalami kejang pasca trauma dini dan sisanya $137(84 \%)$ bebas kejang setelah memulai fenitoin. Sebanyak $19(15,5 \%)$ laki dan $7(17,1 \%)$ perempuan ditemukan mengalami kejang. Berdasakan studi kohort retrospektif yang 
Safa Nabila Zafira, Diva Aulya Kemuning, Nur Izzatush Sholihah, Muhammad Nooradi Praramdana

dilakukan oleh Kwon, dkk (2019) didapatkan bahwa insiden PTS dini adalah 0,9\% (1/116) pada kelompok fenitoin dan 1,4\% (5/365) pada kelompok lacosamide ( $\mathrm{p}=$ 1,00). Advers Drug Events (ADE) akibat penghentian obat pada fenitoin secara signifikan lebih tinggi dibandingkan kelompok lacosamide (5,2\% [6/116]: 0,5\% [2/365]). Tidak ditemukan adanya perbedaan angka mortalitas yang signifikan antara kelompok fenitoin dan lacosamide (7,8\% [9/116]: 4,1\% [15/365]). Sehingga dapat disimpulkan bahwa tidak ditemukan adanya perbedaan kejadian PTS awal antara kedua kelompok fanitoin maupun lacosamide namun fenitoin diketahui memiliki insiden ADE yang lebih tinggi (Kwon et al., 2019).

Berdasakan studi observasional retrospektif yang dilakukan oleh Harris, dkk (2020) didapatkan bahwa penggunaan levetiracetam dikaitkan dengan lama tinggal di rumah sakit yang lebih pendek 6 hari (SD 5,23) dibandingkan pada pengguna fenitoin yakni 12 hari (SD 5,87). Pusing lebih sering terjadi pada pasien yang diobati dengan fenitoin dengan presentase $26 \%$ dibandingkan pusing yang terjadi pada pasien yang diobati dengan levetiracetam dengan presentase $8 \%$. Diketahui bahwa tidak ditemukan adanya korelasi antara skor total GCSdan durasi lama tinggal pasien di trauma unit (Harris et al., 2020).

\section{Pembahasan}

Terapi profilaksis diindikasikan hanya untuk mencegah early PTS pada kasus Cedera Otak Traumatik (COT) berat (GCS <8) namun terapi ini tidak diindikasikan untuk late PTS (>7 hari pasca cedera otak traumatik) (Ruslami \& Bisri, 2016). Penggunaan obat antiepilepsi (OAE) pada kasus TBI dan sebagai profilaksis PTS disarankan digunakan selama 7 hari pasca TBI. Profilaksis kejang merupakan pemberian antikonvulsan kepada pasien yang mengalami cedera kepala untuk mengantisipasi atau mencegah terjadinya kejang (Carney et al., 2017). Indikasi pemberian anti kejang sebagai profilaksis menurut rekomendasi Brain Trauma Foundation yakni adanya skor GCS <10, kontusio kortikal, fraktur depresi kepala, hematoma subdural, hematoma epidural, cedera kepala penetrasi, serta kejadian kejang yang terjadi 24 jam pasca trauma (Javed et al., 2016). Penggunaan OAE sebagai profilaksis dapat menurunkan kejadian PTS pada pasien dengan TBI sedang atau berat. Pada penelitian yang dilakukan Candy dkk pada pasien dengan TBI sedang atau berat dan menerima OAE sebagai profilaksis menunjukkan kejadian PTS yang lebih rendah dibandingkan dengan pasien yang tidak diberikan OAE, yaitu 3,5\% kejadian PTS sedangkan pada pasien yang tidak diberi OAE kejadi PTS sebanyak 8,6\% (Candy, et al., 2019)

Fenitoin merupakan agen profilaksis kejang yang banyak digunakan pada kasus kasus TBI di fase awal dan PTS. Cara kerjanya dengan memberikan efek di korteks motoric dengan mengeluarkan natrium dari neuron sehingga dapat menstabilkan hipereksitabilitas. Fenitoin bekerja melalui inhibisi excitatory synapse dengan cara 
menghambat voltage-gated $\mathrm{Na}+$ channel sehingga menghambat terjadinya depolarisasi dan akhirnya menghambat pelepasan neurotransmiter glutamat vesikular (Ruslami \& Bisri, 2016).

Pada penelitian yang dilakukan Gul dkk pemberian fenitoin diberikan berdasarkan lama cedera otak. Fenitoin yang diberikan $<12$ jam setelah cedera memberikan hasil yaitu $9,89 \%$ pasien mengalami kejang. Sedangkan pada pasien yang diberi fenitoin setelah 12 jam mengalami cedera memberikan hasil yaitu $23,11 \%$ pasien mengalami kejang. Hal ini menunjukkan bahwa pemberian fenitoin $<12$ jam setelah cedera dapat membantu menurunkan kejadian kejang (Gul et al., 2019). Pemberian fenitoin cukup efektif sebagai profilaksis kejang pasca trauma tetapi fenitoin juga memiliki efek samping dan beberapa interaksi obat yang dianggap merugikan (Caballero et al., 2013). Studi oleh Javed, dkk pada tahun 2016 membandingkan pemberian fenitoin dengan pemberian levetiracetam dan dari studi ini tidak didapatkan perbedaan yang cukup signifikan tetapi pemberian levetiracetam diketahui memiliki efek samping jangka panjang yang lebih sedikit dan jarang membutuhkan pemantauan tingkat obat (Javed et al., 2016).

Saat ini levetiracetam belum tersedia dia berbagai tempat layaknya fenitoin, hal ini juga berkaitan dengan biaya per pemakaian levetiracetam yang lebih tinggi (Caballero et al., 2013). Biaya levetiracetam per dosis yakni sekitar 3\$ hingga 22\$ dengan biaya fenitoin per dosis $1 \$$ to $11,5 \$$ (Caballero et al., 2013). Akan tetapi jika dihitung dari total biaya keseluruhan yang dipakai meliputi biaya pemantauan atau monitoring, pemberian levetiracetam memiliki total biaya yang lebih rendah seperti pada penelitian yang dilakukan oleh Caballero, dkk (Caballero et al., 2013). Terkait biaya yang digunakan pada kelompok levetiracetam didapatkan total biaya yang lebih rendah (45 \$/hari) dibandingkan pada kelompok fenitoin ( $83 \$ /$ hari) ( $\mathrm{p}=0,19)$ (Caballero et al., 2013). Obat ini bekerja dengan menghambat ledakan neuron tanpa memengaruhi rangsangan saraf normal dengan cara berikatan secara selektif pada protein vesikular sinaptik SV2A (synaptic vesicle glycoprotein 2A). Ikatan tersebut bersifat reversible, saturable, dan streoselective yang mengubah pelepasan sinaptik glutamat dan GABA melalui mekanisme kerja pada fungsi vesikular. Ini menunjukkan kinetika linier, tidak terikat protein, dan di ekskresikan ke ginjal (Torbic et al., 2013).

Fenitoin dan levetiracetam telah terbukti guna mencegah kejang dini pasca TBI namun penggunaan levetiracetam lebih di rekomendasikan sebagai terapi kejang pasca TBI akut dan jangka pendek, hal ini dikarenakan levetiracetam memiliki efek samping berupa gangguan keseimbangan yang lebih rendah dan lama rawat inap yang lebih singkat dibandingkan fenitoin (Harris et al., 2020).

Efek samping pemberian anti kejang

Penggunaan anti-kejang dalam situasi cedera otak traumatis disarankan selama tujuh hari pertama setelah cedera, obat ini dapat mencegah kejang pasca-trauma dini tetapi tidak dapat mencegah kejang pasca-trauma yang terlambat. Penggunaan obat profilaksis kejang juga memiliki efek samping oleh karena itu penggunaan profilaksis 
Safa Nabila Zafira, Diva Aulya Kemuning, Nur Izzatush Sholihah, Muhammad Nooradi Praramdana

jangka panjang tidak dianjurkan kecuali ada bukti klinis atau bukti EEG kejang (Khan, et al., 2016).

Fenitoin telah terbukti efektif dalam mengatasi berbagai jenis kejang termasuk kejang parsial dan umum. Fenitoin memiliki beberapa efek samping seperti sindrom hipersensitivitas, iritasi kulit atau flebitis ketika terjadi ekstravasasi, hipotensi atau aritmia ketika diberikan secara intravena, hipotensi, nistagmus, diplopia, ataxia, reaksi kulit yang serius dan dapat berdampak pada fungsi kognitif jangka panjang (Ruslami \& Bisri, 2016). Selain itu terdapat pula efek samping lainnya berupa adanya interaksi obat, reaksi berbahaya (cardiotoxicity), sindrom sensitivitas anti kovulsan, sindrom StevenJohnson dan nekrosis jaringan. Pada pemakaian terapinya, fenitoin membutuhkan pemantauan karena termasuk dalam kategori farmakokinetik non-linier (Harris et al., 2020). Penggunaan dalam jangka waktu yang lama dapat menimbulkan hiperplasia gusi, neuropati perifer, defisiensivitamin D, hipotensi dan reaksi hipersensitivitas (Ruslami \& Bisri, 2016).

Jika dibandingkan dengan fenitoin, levetiracetam memiliki komplikasi yang lebih rendah dan lebih aman karena penggunaan levetiracetam tidak memengaruhi fungsi keseimbangan dan dapat ditoleransi oleh tubuh dalam jangka waktu yang cepat pada pasien dengan skor total GCS 14-15 sehingga levetiracetam dapat digunakan sebagai terapi tunggal dan dapat direkomendasikan untuk pasien yang lebih tua namun dalam kategori penggunaan jangka panjang, levetiracetam dapat menimbulkan komplikasi neuropsikiatri (Harris et al., 2020).

Penggunaan lacosamide telah terbukti memiliki efektifitas dan keamanan yang lebih baik pada pasien yang dirawat di ruang ICU terutama dengan status epileptikus refrakter namun pada beberapa pasien obat ini dapat menimbulkan Advers Drug Events (ADE) yang apabila bergejala menyebabkan bradikardi dan halusinsi sehingga perlu adanya pertimbangan untuk segera dihentikan (Kwon et al., 2019).

\section{Kesimpulan}

Levetiracetam memiliki efek samping yang lebih sedikit daripada fenitoin dan lacosamide sehingga penggunaan obat ini lebih dianjurkan untuk digunakan. Pemberian anti kejang pada kasus kejang pasca traumatic brain injury (TBI) atau post traumatic seizure (PTS) digunakan sebagai usaha profilaksis kejang dengan rekomendasi pemakaian kurang dari delapan hari karena OAE terbukti memiliki beberapa efek samping setelah penggunaannya termasuk dapat meningkatkan angka mortilitas. Terkhusus pada pemberian fenitoin dan lacosamide diperlukan adanya pemantauan saat penggunaannya. 
Penggunaan Antikejang Pada Cedera Kepala: Tinjauan Sistematis

\section{BIBLIOGRAFI}

Caballero, G. C. et al. (2013) 'Retrospective Analysis of Levetiracetam Compared to Phenytoin for Seizure Prophylaxis in Adults with Traumatic Brain Injury', Hospital Pharmacy, 48(9), pp. 757-761. Google Scholar

Candy, N., Tsimiklis, C., Poonnoose, S., \& Trivedi, R. 2019. The use of antiepileptic medication in early post traumatic seizure prophylaxis at a single institution. Journal of Clinical Neuroscience, 69, 198-205. Google Scholar

Carney, N. et al. (2017) 'Guidelines for the Management of Severe Traumatic Brain Injury, Fourth Edition', Neurosurgery, 80(1), pp. 6-15. Google Scholar

Center for Disease Control and Prevention 2019, 'Traumatic Brain Injury \& Concussion', Symptoms of Traumatic Brain Injury, $2019 . \quad$ Google Scholar

Gul, N., Khan, S. A., Khattak, H. A., Muhammad, G., Khan, A. A., Khan, I., \& Aurangzeb, A. (2019). Efficacy Of Phenytoin In Prevention Of Early Posttraumatic Seizures. Journal of Ayub Medical College, Abbottabad: JAMC, 31(2), 237-241. Google Scholar

Harris, L., Hateley, S., Tsang, K., Wilson, M., \& Seemungal, B. (2020). Impact of Antipileptic drug choice on discharge in Acute Traumatic Brain Injury Patients. Journal of Neurology, 267, 1774-1779. Google Scholar

Javed, G. et al. (2016) 'Use of levetiracetam in prophylaxis of early post-traumatic seizures', Turkish Neurosurgery, 26(5), pp. 732-735. Google Scholar

Khan, S. A., Bhatti, S. N., Alam, A., Afridi, E. A. K., Muhammad, G., Zadran, K. K., \& Aurangzeb, A. 2016. Comparison of efficacy of phenytoin and levetiracetam for prevention of early post traumatic seizures. Journal of Ayub Medical College Abbottabad, 28(3), 455-460. Google Scholar

Kwon, S. J., Barletta, J. F., Hall, S. T., Mangram, A. J., Dzandu, J. K., Abdulhamid, M., \& Zach, V. (2019). Lacosamide versus Phenytoin for The Prevention of Early Post Traumatic Seizure. Journal of Critical Care, 50, 50-53. Google Scholar

Lamar, C. D., Hurley, R. A., Rowland, J. A. \& Taber, K. H., 2014. Post-Traumatic Epilepsy: Review of Riks, Pathophysiology, and Potential Biomarkers. The Journal of Neuropsychiatry and Clinical Neurosciences, 26(2), pp. 108-113. Google Scholar

Laskowitz, D \& Grant, G 2016, Translational Research in Traumatic Brain Injury, Google Scholar

Lucke-Wold, BP, Nguyen, L, Turner, RC, Logsdon, AF, Chen, Y-W, Smith, KE, Huber, JD, Matsumoto, R, Rosen, CL, Tucker, ES \& Richter, E 2015, 'Traumatic Brain Injury and Epilepsy: Underlying Mechanisms Leading to Seizure', Elsevier, pp. 13-23, Google Scholar

Michael C Dewan. MD. (2018) 'Estimating the global incidence of traumatic brain injury'MSCI NHS England 2019, 2019, Google Scholar 
Safa Nabila Zafira, Diva Aulya Kemuning, Nur Izzatush Sholihah, Muhammad Nooradi Praramdana

Prins, M., Greco, T., Alexander, D. \& Giza, C. C., 2013. The pathophysiology of traumatic brain injury at a glance. Disease Models \& Mechanisms. 6(6), pp. 13071315. Google Scholar

Randolph W Evans, MD, FAANSteven C Schachter, MD (2020) 'Post traumatic seizures and epilepsyPost-Traumatic Seizure, Lindsay Raab, 2020' Google Scholar

Shaikh, F. and Waseem, M. (2021) Head Trauma, StatPearls. StatPearls Publishing. Available at: http://www.ncbi.nlm.nih.gov/pubmed/28613604 (Accessed: 16 April 2021).

Sharma, R. et al., 2019. Neuroinflammation in Post-Traumatic Epilepsy: Pathophysiology and Tractable Therapeutic Targets. Brain Sciences, 9(11), pp. 125. Google Scholar

Schmidt, D. and Schachter, S. C. (2014) 'Drug treatment of epilepsy in adults', BMJ (Online), 348(November). doi: 10.1136/bmj.g254. Google Scholar

Sudadi, 2017. Brain Protection pada Traumatic Brain Injury. Jurnal Komplikasi Anestesi, 5(1), pp. 59-65. Google Scholar

Torbic, H. et al. (2013) 'Use of antiepileptics for seizure prophylaxis after traumatic brain injury', American Journal of Health-System Pharmacy, 70(9), pp. 759-766. doi: 10.2146/ajhp120203. Google Scholar

Valeria Pingue, Chiara Mele\& Antonio Nardone. (2021) 'Post-traumatic seizures and antiepileptic therapy as predictors of the functional outcome in patients with traumatic brain injury' Google Scholar

Verellen, R. M. and Cavazos, J. E. (2010) 'Post-traumatic epilepsy: An overview', Therapy, 7(5), pp. 527-531. doi: 10.2217/thy.10 Google Scholar

First publication right:

Jurnal Syntax Fusion: Jurnal Nasional Indonesia

This article is licensed under:

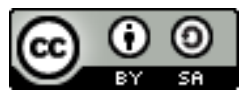

